\title{
Divergent translations of terminology in texts of European political institutions in human and machine Google translation
}

\section{[Divergencia prekladu terminologických jednotiek $\mathrm{v}$ textoch európskych politických inštitúcií v l'udskom a strojovom Google preklade]}

\author{
Lydia Cechova - Martin Macura - Lenka Kubusova - Zuzana Janosikova
}

\section{DOI: $10.18355 /$ XL.2017.10.02.01}

\begin{abstract}
The paper deals with the quality of Google translation of the terms used in the European political institutions. Our research opens up the following questions: To what extent is Google capable of translating a word with an exactly precise definition? Can unprofessional translators rely on Google accuracy? Will Google translation of EU terms (based on frequency principle) be similar to human choice of terms? Do the most frequent equivalents in machine Google translation correspond with the human translation?
\end{abstract}

Key words: Machine translation, Human translation, Google Translate, European Political Institutions, Machine Translation Archive

\section{Anotácia}

Vo výskume sme sa zamerali na výskum kvality Google prekladu v oblasti terminológie európskych politických inštitúcií. Sledovali sme, do akej miery je Google schopný preložit' slovo, ktoré má exaktnú definíciu, a či sa môže laický prekladatel' spol'ahnút' na správnost' jeho prekladu. Hlavnou otázkou výskumného projektu bolo, či bude kvalitatívne vyhodnotenie strojového prekladu termínov EÚ v Prekladači Google založené na princípe frekvencie analogické s l’udským prekladom. Sledovali sme teda úroveň zhody najfrekventovanejších prekladových ekvivalentov v strojovom preklade Google a v l'udskom preklade.

Kl’účové slová: strojový preklad, l’udský preklad, Google translator, európske politické inštitúcie, archív strojového prekladu

\section{Úvod}

Preklad sa v dnešnej dobe chápe nielen ako jazyková operácia na povrchovej alebo híbkovej úrovni jazyka, no stal sa javom, ktorý integruje sociálne, kultúrne, politické, etické, filozofické, náboženské a iné aspekty s aspektmi lingvistickými, jazykovými, pragmatickými, realizačnými, technickými a logistickými. Ciel’om je poskytnút' komplexný produkt vyhovujúci po stránke formálnej, obsahovej, grafickej, technickej a jazykovej. Preklad je teda aj technická operácia. V tejto oblasti je potrebné spomenút' aplikáciu nových technológií, ktoré si translatológia - veda o preklade - osvojila za posledných niekol'ko rokov a ktoré sú výsledkom lingvistického a prekladatel'ského výskumu (najmä v USA a Rusku), ktorý sa začal už v období studenej vojny.

Pod strojovým prekladom rozumieme samostatný počítačom realizovaný preklad originálneho textu do ciel'ového textu bez pomoci alebo zásahov človeka. Pod termínom počitačom podporovaný preklad rozumieme preklad realizovaný človekom - prekladatel'om - za pomoci počítačového softvéru, najmä softvéru na prekladatel'skú pamät' alebo iného prekladatel'ského softvéru, napr. na príncípe „work- 
bench“. Počítačom podporovaný a strojový preklad sú zložité operácie, pretože okrem základných prekladatel'ských postupov a teórií sa $\mathrm{v}$ nich aplikujú postupy na počítačovú a štatistickú analýzu jazyka, aplikačné roviny teoretickej lingvistiky (parsing, tagging, syntéza atd'.), spracovávanie prirodzených jazykov, počítačová sémantika, umelá inteligencia, automatická indexácia a sumarizácia textu, sémantická analýza textu, extrakcia informácií z textu, rozoznávanie reči, syntéza reči, používanie slovníkových databáz a slovníková lingvistika, používanie korpusov, používanie bilingválnych a multilingválnych paralelných korpusov, terminologická extrakcia atd'. Výskum v oblasti strojového prekladu sa polarizoval na dve základné výskumné oblasti - empirický, teda praktický výskum s aplikáciou štatistických metód a teoretický výskum s použitím gramatickej analýzy jazyka a tvorby gramatických jazykových modelov. V empirickom prístupe sa často aplikovala priama metóda prekladu, teda náhrada výrazu výrazom na báze počítačového slovníka, náhrada slova za slovo alebo konštrukcie za konštrukciu, a to bez híbkovej analýzy viet a ich významu, často s použitím metód štatistickej analýzy bilingválnych a monolingválnych textov. V teoretickom prístupe $\mathrm{k}$ počítačovému prekladu sa presadzuje teoretická analýza prekladaných viet $\mathrm{z}$ hl'adiska štruktúry (surface level) a významu (deep level). Výsledkom týchto dvoch prístupov je tvorba dvoch základných typov programov na strojový preklad - śtatistických a ,pravidlových“.

Strojový preklad bol spočiatku vnímaný vel'mi skepticky a mnohí sa k nemu stavali odmietavo. V ostatnom čase nastal výrazný posun a dokonca aj profesionálni prekladatelia ho zarad'ujú $\mathrm{k}$ dôležitým pomôckam na ul'ahčenie práce v prekladatel'skom procese. Strojový preklad sa dá, podl'a D. Munkovej (2013: 17), využit' ako a. prvotný, resp. náhradný preklad v prípade, že sa čaká na prekladatel'a, b. pracovný typ prekladu, ktorý je pre danú situáciu postačujúci, c. hrubý náčrt, na ktorom bude prekladatel' pracovat' v d'alších krokoch, d. spôsob metódy výučby $\mathrm{v}$ odbore prekladatel'stvo.

D. Munková (2013: 20) konkrétnejšie opisuje jednotlivé zložky, ktoré tvoria neodmyslitel'nú súčast' procesu strojového prekladu. Patria sem lingvistické korpusy, systémy na úpravu dokumentov a v neposlednom rade, samozrejme, prekladacie systémy, ktorých úlohou je preložit' originálny text do ciel’ového jazyka. Tvrdí, že pre lepšie pochopenie strojového prekladu je dôležité poznat' jednotlivé kroky tohto procesu. Prvá fáza spočíva v príprave dokumentu, to je tzv. intrajazykový preklad, pretože prekladatel' musí upravit', pre-editovat' text, aby vyhovoval podmienkam strojového prekladu. Následne sa do procesu zapoja prekladacie systémy, ktoré využívajú lingvistické korpusy, rôzne slovníky a rovnako aj pravidlá naprogramované vo forme algoritmov. Túto fázu už označujeme ako medzijazykový preklad. Tretím, posledným krokom, je opät' intrajazykový preklad, t.j. revízia translátu, kde sa vyžaduje účast' prekladatel'a.

Takmer od počiatkov strojového prekladu sa prístupy v tejto oblasti rozdelili do dvoch opozičných skupín. Podl’a M. Mačuru (Muglova, 2009: 292) prvú skupinu predstavuje empirický pristup - v počítačovom preklade sa využíva ,priama metóda prekladu..., t.j. náhrada slova za slovo alebo konštrukcie za konštrukciu bez híbkovej analýzy viet a ich významu. “ Jeho náprotivkom je teoretický pristup, v ktorom sa uprednostňovala „teoretická analýza prekladaných viet a ich významu, akési pochopenie vety počitačom. " Tieto dva prístupy priniesli ako výsledok svojho výskumu aj dnes často využívané automatické programy na preklad a rôzne druhy pomocných, resp. asistenčných programov.

$\mathrm{Aj}$ napriek tomu, že sa $\mathrm{v}$ ostatných desat'ročiach rapídne zvýšil záujem o strojový preklad a dosiahol sa aj výrazný kvalitatívny posun, nachádzame určité 
nedokonalosti $\mathrm{v}$ mechanizme ich prekladatel'ského procesu, ktoré sa premietnu do výsledného produktu. Zatial' nemožno bez intervencie l'udského činitel'a aplikovat' strojový preklad na všetky druhy textov. Vo všeobecnosti sa preferuje názor, že strojový preklad možno aplikovat' hlavne na odborný preklad. Informatívne texty sú totižto založené najmä na strohom a priamočiarom odovzdávaní informácií, údajov a ako sme už uviedli, sú nasýtené termínmi, ktorých preklad je vždy rovnaký. Texty odborného štýlu sú menej náročné z morfologického, syntaktického i štylistického hl'adiska.

Vzhl'adom na to, že sa $\mathrm{v}$ ostatnom období venuje strojovému prekladu mimoriadna pozornost' a rovnako narastá potreba prekladu dokumentov z Európskej únie, rozhodli sme sa spojit' tieto dva javy. Predmetom nášho výskumu bolo zhodnotenie kvality translátu strojového prekladu v oblasti odborných textov. Špecifickou oblast'ou nášho záujmu bolo hodnotenie kvality prekladu najpoužívanejších terminologických jednotiek, resp. najfrekventovanejších termínov v inštitúciách EÚ prostredníctvom prekladača Google.

Výskumom terminologických jednotiek sme sa snažili predostriet' a poskytnút' teoretický náhl’ad na danú problematiku, pretože na dosiahnutie objektívnych výsledkov by výskum musel nadobudnút' podstatne väčšie kvantitatívne rozmery. Pre zvolenú terminológiu sme sa rozhodli $\mathrm{z}$ dôvodu jej pomerne jednoduchej analyzovatel'nosti, monosémantickosti, špecifickosti a relatívnej jednoduchosti sledovania javov. Zaujímalo nás, do akej miery je Google schopný preložit' slovo, ktoré má exaktnú definíciu, a či sa môže laický prekladatel' spol'ahnút' na správnost' jeho prekladu. Zároveň nás zaujímalo, do akej miery je Google pri preklade terminologických jednotiek divergentný v porovnaní s l'udským prekladatel'om.

Predmetom nášho výskumu bola terminologická sústava Európskej únie, pre ktorú sme sa rozhodli predovšetkým z dvoch dôvodov. Prvým je potreba prekladu tohto typu textov a ich náročnost'. Obzvlášt' problematický je preklad právnych textov Európskej únie, ako to potvrdzuje E. Dekanová (2009: 16): „Proces štandardizácie a unifikácie národných právnych systémov a ich zosúladenie s nadnárodným európskym právnym systémom je zložitý jav." Prekladatel' stojí preto v procese prekladu terminológie EÚ pred náročnou úlohou. Musí zabezpečit', aby ciel'ový text spíňal požadované kritériá a aby taktiež zodpovedal všeobecne platnému úzu a norme ciel'ového právneho jazyka. Ešte $\mathrm{v}$ polovici minulého storočia vymedzila francúzskokanadská škola porovnávacej štylistiky prekladatel'ské postupy, ktoré sa využívajú pri preklade termínov a terminologických výrazov (Hajikova, 2005: 13), medzi ktoré patria modulácia, transpozícia, kalky a výpožičky. Aspektu l'udského prekladu sa však v našom výskume venovat' nebudeme. Naša pozornost' sa upriamuje na strojový preklad termínov EÚ.

Skôr než predstavíme jednotlivé výsledky nášho výskumu, v krátkosti opíšeme programy, s ktorými sme pracovali.

\section{Prekladač Google (Google Translate)}

Google Translate k dnešnému dňu pracuje s viac ako 90 svetovými jazykmi a je založený na dvojjazyčnom paralelnom korpuse človekom vytvorených textov. Nie je viazaný žiadnymi prekladovými pravidlami. Vychádza skôr z dostupných textov, ktoré mu slúžia ako vzor na odhadnutie určitých gramatických pravidiel. Vel'kým plusom je využitie tzv. frázovej tabul'ky, vd'aka ktorej môže preložit' celý významový segment a nielen jednotlivé slová. Najvhodnejšie slovné spojenie vyberá na základe jazykového modelu z jednojazykového korpusu ciel’ového jazyka. 
Google využíva Machine Translation Archive, databázu strojových prekladov, ktorá obsahuje zbierku anglických textov od roku 1990 a postupne sa spracúvajú aj staršie texty zhruba z 50. rokov minulého storočia, ked’ bol strojový preklad vo svojich začiatkoch. Okrem databázy pracuje prekladač v prekladatel'skom procese s množstvom softvérov, dekóderov a presne stanovených algoritmov.

Spoločnost' Google ponúka dokonca využitie služby Translation Toolkit, v ktorej si používatel' môže preložit' celý textový dokument ako celok, vytvorit' si vlastný archív textov či glosár a ktorá obsahuje širokú škálu d’alších iných funkcií a nástrojov. Väčšina z nich je bezplatná, ale možno nájst' aj spoplatnené nástroje, ako napríklad Translate API alebo Translation Gadget.

\section{Program TextSTAT}

Vd’aka programu TextSTAT sme mohli vyhl'adávat' jednotlivé termíny, ktoré boli zoradené podl'a frekvencie ich používania v databáze originálnych anglických textov. TextSTAT je lingvistický korpusový program vyvinutý na berlínskej Freie Universität. Na internete je dostupná aj jeho bezplatná verzia. Okrem možnosti vytvorenia vlastného korpusu poskytuje použivatel'om využivat' aj nástroje na analýzu textov. TextSTAT pracuje s rôznymi typmi dokumentov (.txt, .doc, .html). Ďalšími zaujímavými funkciami je napr. web spider, ktorý umožňuje operovat' s textami dostupnými na internete; Query editor, ktorý slúži na vyhl'adávanie kolokácií, t.j. ustálených slovných spojení. Výsledky analýz môžu byt' uložené v rôznych formátoch: CSV, súbor programu Excel alebo Word.

\section{Program ApSIC Xbench}

Softvér ApSIC Xbench, vyvinutý španielskou prekladatel'skou agentúrou ApSIC, má dve kl'účové funkcie. V prvom rade hromadí l'ubovol'ný počet glosárov a bilingválnych textov (môžu zahŕňat' slovníky, prekladatel'skú pamät' i iné pracovné súbory) a umožňuje $\mathrm{v}$ nich spätné vyhl'adávanie potrebných pojmov. Druhou funkciou je kontrola kvality bilingválnych textov. My sme ho v našom výskume použili na presné určenie výskytu konkrétnych termínov v l'udskom aj strojovom transláte. Xbench poskytuje funkciu tzv. konkordancie, čiže obojstranného vyhl'adávania výrazovej zhody a časti vety s predchádzajúcim prekladom a zároveň môže súčasne vyhl'adávat' aj v slovníku. Jednotlivým súborom môžete dokonca pridat' stupeň priority, resp. dôležitosti, a ten sa zobrazí vo vyhl'adávacom políčku. Ďalšou zaujímavost'ou je nástroj zabezpečovania kvality $Q A-Q u a l i t y$ Assurance. Softvér ApSIC Xbench pracuje bez ohl'adu na použité prekladatel'ské prostredie a umožňuje operovat's viacerými typmi formátov.

V našom výskume sme pri hodnotení a porovnávaní ekvivalentov strojového a l'udského prekladu pracovali najmä s týmito troma prekladatel'skými pomôckami. $\mathrm{Na}$ začiatku výskumného projektu sme si položili otázku, či bude kvalitatívne vyhodnotenie strojového prekladu termínov EÚ v Prekladači Google založené na princípe frekvencie analogické s l’udským prekladom. Sledovali sme teda zhodu najfrekventovanejších prekladových ekvivalentov v strojovom preklade Google a v l'udskom preklade.

Výskum sme rozdelili do niekol'kých fáz. Prvou fázou bolo spracovanie l’udského_prekladu. Najskôr sme si vytvorili databázu, ktorá pozostávala približne z 20000 východiskových anglických viet z dokumentov inštitúcií EÚ. K tomu sme paralelne zostavili databázu viet v slovenskom jazyku, ktoré boli preložené l’udským prekladatel'om. Program TestSTAT vygeneroval z pôvodných východiskových anglických viet poradie najfrekventovanejších terminologických jednotiek, z ktorých 
sme zostavili vzorku 20 anglických termínov z databázy východiskových textov. V druhom kroku sme túto vzorku preložili do slovenčiny, pričom sme sa snažili zachytit' všetky možné ekvivalenty $\mathrm{v}$ danom kontexte. $\mathrm{V}$ tretej fáze sme do výskumného procesu zapojili program ApSIC Xbench. V ňom sme porovnali našu vzorku termínov s bilingválnou databázou anglických východiskových a slovenských prekladových textov s tematikou z oblasti EÚ, ktoré vytvoril l'udský prekladatel'. Následne program vygeneroval presný číselný údaj, ktorý vyjadroval mieru zastúpenia každého nami preloženého ekvivalentu daného anglického termínu $\mathrm{v}$ databáze slovenských prekladových textov z pera l'udského prekladatel'a. Číselné údaje sme spracovali do podoby tabul'ky s názvom Ludský a strojový preklad (tab. 1) a detailne sme uviedli ich súčet a percentuálne zastúpenie v l'udskom preklade.

Krok č. 4 predstavoval prácu so strojovým prekladom. Postupovali sme identicky ako v tretej fáze. Jediným rozdielom bolo, že do programu ApSIC Xbench sme okrem databázy anglických východiskových viet vložili aj ich slovenský preklad vygenerovaný prostredníctvom strojového prekladu Google. Získané číselné údaje a percentuálne vyjadrenie sme uviedli v tabul'ke s názvom L'udský a strojový preklad (tab. 1).

Ludský a strojový preklad (tab. 1)

\begin{tabular}{|c|c|c|}
\hline & L'UDSKÝ PREKLAD & STROJOVÝ PREKLAD \\
\hline $\begin{array}{l}\text { FREKVENTOVANÉ } \\
\text { TERMÍNY }\end{array}$ & PREKLAD DO SJ & PREKLAD DO SJ \\
\hline 1. MEMBER & člen - $2998(100 \%)$ & člen - $3306(100 \%)$ \\
\hline 2. EUROPEAN & európsky - 1634 (100\%) & európsky - 2033 (100\%) \\
\hline 3. COMMISSION & $\begin{array}{l}\text { 1) komisia- } 389(74 \%) \\
\text { 2) výbor - } 140(26 \%) \\
\text { 3) úrad - 0 } \\
\text { spolu ekvivalentov: } 529\end{array}$ & $\begin{array}{l}\text { 1) komisia - } 1299(85 \%) \\
\text { 2) výbor - } 162(11 \%) \\
\text { 3) úrad - } 62(4 \%) \\
\text { spolu ekvivalentov: } 1523\end{array}$ \\
\hline 4.ARTICLE & $\begin{array}{l}\text { 1) článok - } 2514(100 \%) \\
\text { 2) bod - } 0 \\
\text { 3) paragraf - } 0 \\
\text { 4) stat' - 0 } \\
\text { spolu ekvivalentov: } 2514\end{array}$ & $\begin{array}{l}\text { 1) článok - } 3475(100 \%) \\
\text { 2) bod -0 } \\
\text { 3) paragraf - } 0 \\
\text { 4) stat'-0 } \\
\text { spolu ekvivalentov: } 3475\end{array}$ \\
\hline 5. STATE & štát - $2915(100 \%)$ & štát - $3288(100 \%)$ \\
\hline
\end{tabular}




\begin{tabular}{|c|c|c|}
\hline 6. COUNCIL & $\begin{array}{l}\text { 1) rada }-1559(100 \%) \\
\text { 2) výbor }-0 \\
\text { 3) zasadnutie }-0 \\
\text { spolu ekvivalentov: } 1559\end{array}$ & $\begin{array}{l}\text { 1) rada }-543(90,61 \%) \\
\text { 2) výbor - } 150(5,50 \%) \\
\text { 3) zasadnutie - } 51(3,89 \%) \\
\text { spolu ekvivalentov: } 744\end{array}$ \\
\hline 7. DIRECTIVE & $\begin{array}{l}\text { 1) smernica }-1242(100 \%) \\
\text { 2) direktíva - } 4(0 \%) \\
\text { 3) pokyn - } 0 \\
\text { spolu ekvivalentov: } 1246\end{array}$ & $\begin{array}{l}\text { 1) smernica }-1399(100 \%) \\
\text { 2) direktíva }-0 \\
\text { 3) pokyn }-0 \\
\text { spolu ekvivalentov: } 1399\end{array}$ \\
\hline 8. MARKET & $\operatorname{trh}-950(100 \%)$ & $\operatorname{trh}-1167(100 \%)$ \\
\hline 9. PARLIAMENT & parlament $-426(100 \%)$ & parlament $-581(100 \%)$ \\
\hline 10. NATIONAL & $\begin{array}{l}\text { 1) národný - } 1062(68 \%) \\
\text { 2) štátny - } 192(12 \%) \\
\text { 3) vnútroštátny - 301 }(19 \%) \\
\text { spolu ekvivalentov: } 1555\end{array}$ & $\begin{array}{l}\text { 1) národný }-1242(65 \%) \\
\text { 2) štátny }-218(11 \%) \\
\text { 3) vnútroštátny }-455(24 \%) \\
\text { spolu ekvivalentov: } 1915\end{array}$ \\
\hline 11. POLICY & $\begin{array}{l}\text { 1) politika - } 426(99 \%) \\
\text { 2) stratégia }-3(1 \%) \\
\text { spolu ekvivalentov: } 429\end{array}$ & $\begin{array}{l}\text { 1) politika }-567(95 \%) \\
\text { 2) stratégia }-32(5 \%) \\
\text { spolu ekvivalentov: } 599\end{array}$ \\
\hline 12. MEASURES & $\begin{array}{l}\text { 1) opatrenia - } 644(91 \%) \\
\text { 2) miery - } 61(9 \%) \\
\text { spolu ekvivalentov: } 705\end{array}$ & $\begin{array}{l}\text { 1) opatrenia }-807(98 \%) \\
\text { 2) miery }-15(2 \%) \\
\text { spolu ekvivalentov: } 822\end{array}$ \\
\hline 13. AMENDMENT & $\begin{array}{l}\text { 1) dodatok - } 7(7 \%) \\
\text { 2) novela - } 1(1 \%) \\
\text { 3) zmena - 86 (91\%) } \\
\text { spolu ekvivalentov: } 94\end{array}$ & $\begin{array}{l}\text { 1) dodatok }-5(4 \%) \\
\text { 2) novela - } 3(2 \%) \\
\text { 3) zmena - } 117(94 \%) \\
\text { spolu ekvivalentov: } 125\end{array}$ \\
\hline
\end{tabular}




\begin{tabular}{|c|c|c|}
\hline 14.UNION & $\begin{array}{l}\text { 1) únia }-593(100 \%) \\
\text { 2) jednota }-0 \\
\text { 3) spojenie }-0 \\
\text { spolu ekvivalentov: } 593\end{array}$ & $\begin{array}{l}\text { 1) únia }-123(99 \%) \\
\text { 2) jednota }-1(1 \%) \\
\text { 3) spojenie }-0 \\
\text { spolu ekvivalentov: } 124\end{array}$ \\
\hline 15. COMMITTEE & výbor - $240(100 \%)$ & výbor $314(100 \%)$ \\
\hline 16. AUTHORITIES & $\begin{array}{l}\text { 1) orgány }-520(100 \%) \\
\text { 2) predstavitelia }-1(0 \%) \\
\text { 3) činitelia - } 1(0 \%) \\
\text { spolu ekvivalentov: } 522\end{array}$ & $\begin{array}{l}\text { 1) orgány }-622(100 \%) \\
\text { 2) predstavitelia }-2(0 \%) \\
\text { 3) činitelia }-0 \\
\text { spolu ekvivalentov: } 624\end{array}$ \\
\hline $\begin{array}{l}\text { 17. IMPLEMENTA- } \\
\text { TION }\end{array}$ & $\begin{array}{l}\text { 1) implementácia - } 76 \\
(48 \%) \\
\text { 2) zavedenie }-30(19 \%) \\
\text { 3) vykonanie }-35(22 \%) \\
\text { 4) realizácia }-18(11 \%) \\
\text { spolu ekvivalentov: } 159\end{array}$ & $\begin{array}{l}\text { 1) implementácia - } 40 \\
(30 \%) \\
\text { 2) zavedenie }-28(21 \%) \\
\text { 3) vykonanie }-27(20 \%) \\
\text { 4) realizácia - } 40(30 \%) \\
\text { spolu ekvivalentov: } 135\end{array}$ \\
\hline 18. TREATY & $\begin{array}{l}\text { 1) zmluva }-645(89 \%) \\
\text { 2) dohoda }-80(11 \%) \\
\text { 3) pakt - } 3(0 \%) \\
\text { spolu ekvivalentov: } 728\end{array}$ & $\begin{array}{l}\text { 1) zmluva }-860(91 \%) \\
\text { 2) dohoda }-78(8 \%) \\
\text { 3) pakt }-7(1 \%) \\
\text { spolu ekvivalentov: } 945\end{array}$ \\
\hline 19. LEGISLATION & $\begin{array}{l}\text { 1) legislatíva }-90(24 \%) \\
\text { 2) právne predpisy }-290 \\
\text { ( } 76 \%) \\
\text { spolu ekvivalentov: } 380\end{array}$ & $\begin{array}{l}\text { 1) legislatíva } 47(11 \%) \\
\text { 2) právne predpisy - } 389 \\
(89 \%) \\
\text { spolu ekvivalentov: } 436\end{array}$ \\
\hline 20. INSTITUTION & $\begin{array}{l}\text { 1) inštitúcia - } 844(94 \%) \\
\text { 2) ústav - } 57 \text { (6\%) } \\
\text { spolu ekvivalentov: } 901\end{array}$ & $\begin{array}{l}\text { 1) inštitúcia - } 1051(96 \%) \\
\text { 2) ústav - } 47 \text { ( } 4 \%) \\
\text { spolu ekvivalentov: } 1098\end{array}$ \\
\hline
\end{tabular}


Z uvedených tabuliek jednoznačne vyplýva, že l'udský a strojový výber prekladových ekvivalentov je vel'mi podobný. Istú paralelu môžeme pozorovat' aj pri percentuálnom vyjadrení a miere zastúpenia. Vyšší výskyt jednotlivých ekvivalentov v strojovom preklade pripisujeme tomu, že program automaticky kopíruje originál. Ludský prekladatel' zvažuje aspekt redundantnosti či častého opakovania slov a pre lepšiu prehl'adnost' textu slovo vynechá alebo ho nahradí zámenom. $\mathrm{Z}$ terminologického aspektu je zaujímavé si všimnút, že Google ponúka v priemere 1,95 možností ekvivalentov na pôvodný anglický termín, pričom l'udský prekladatel' zvažuje podobne 1,85 možných ekvivalentov. Položili sme si otázku, či je najčastejšie použitý ekvivalent v l'udskom a v strojovom preklade rovnaký. Odpoved'ou štatistiky je prekvapivý výsledok - v 80\% vybral človek a prekladač Google ten istý ekvivalent. Ďalším zaujímavým výsledkom je, že najčastejšie použitý ekvivalent predstavuje celkovo $91,5 \%$ v texte l’udského prekladu a v strojovom preklade Google nám vyšiel podobný výsledok - 90,7\%. Náš výskum jasne dokazuje, že strojový preklad Google je spol'ahlivou prekladatel'skou pomôckou z hl'adiska prekladu termínov EÚ pre laických i pre profesionálnych prekladatel'ov či širokú verejnost'. Nesporne by bolo zaujímavé zrealizovat' výskum aj v inej tematickej oblasti a zistit', či strojový preklad skutočne dokáže uchopit' širokú škálu tematických okruhov. Ak by d’alšie výskumy priniesli podobné výsledky, potvrdilo by sa, že ,prirodzený jazyk môže byt' dokonale popísaný symbolmi a značkami, plne analyzovaný, kontrolovaný a matematický kódovany"“ (Munkova, 2013: 12).

\section{Je najfrekventovanejši ekvivalent ten istý v ludskom aj $v$ strojovom preklade?}

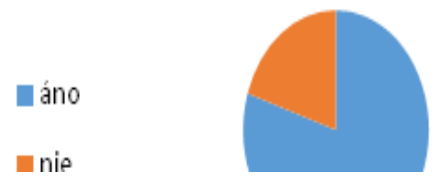

Obr. 1: Zhoda najfrekventovanejších ekvivalentov v l'udskom a strojovom preklade

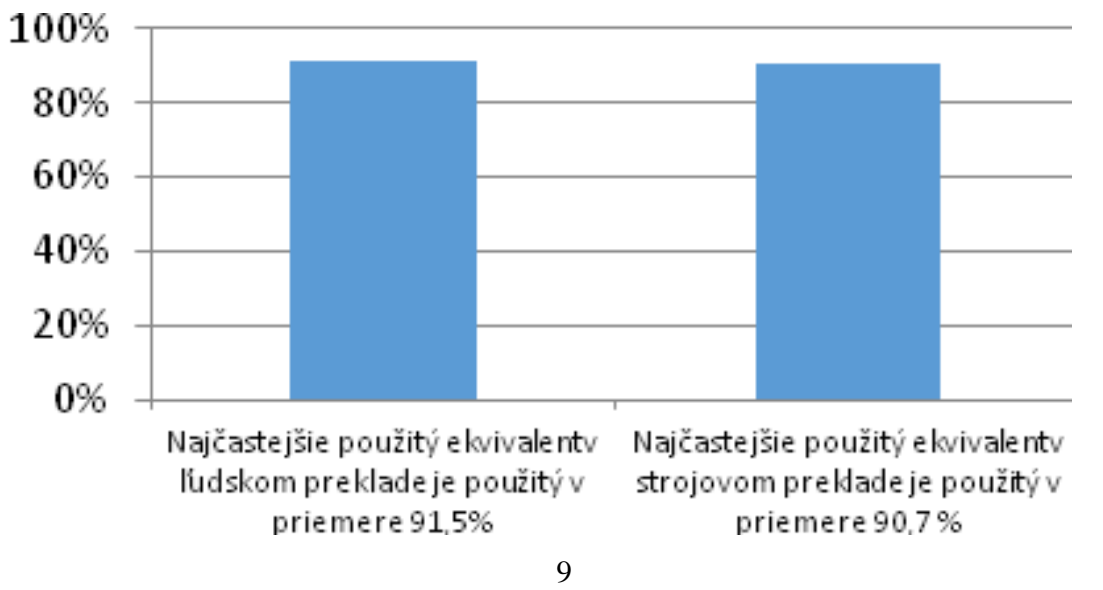

XLinguae Journal, Volume 10 Issue 2, April 2017, ISSN 1337-8384 


\section{Obr. 2: Porovnanie najčastejšie použitého ekvivalentu v l'udskom a strojovom preklade}

V poslednej fáze sme sa rozhodli, že predmet nášho záujmu rozšírime zo samostatných jednoslovných termínov aj na ustálené, často používané terminologické spojenia, spojené podstatné mená, kolokácie a iné. To znamená, že k už zhodnotenej vzorke 20 najfrekventovanejších jednoslovných termínov sme našli kolokácie, resp. frázy, ktoré sa v texte objavujú najfrekventovanejšie. Vzhl'adom na skutočnost', že ide o termíny z oblasti prekladu dokumentov EÚ, na vyhl'adanie najfrekventovanejších ustálených terminologických spojení sme použili Inter-Active Terminology for Europe IATE. Tento zdroj predstavuje multilingválnu terminologickú databázu, ktorá vznikla v roku 2004 a spracúvajú sa v nej texty partnerských inštitúcií a agentúr EÚ. Východiskovým bodom bol pre nás už vytvorený zoznam najfrekventovanejších jednoslovných termínov. Tie sme jednotlivo vkladali do prehliadača IATE, kde sme si z ponúknutých možností vybrali tie, ktoré boli z hl'adiska vyhl'adávania a použitia na prvom mieste. Opät' sme ich za pomoci programu ApSIC Xbench porovnali z hl'adiska l'udského a strojového prekladu. V tab. 2 uvádzame aj konkrétne číselné údaje i percentuálne zastúpenie.

\section{Ludský a strojový preklad (tab. 2)}

\begin{tabular}{|c|c|c|}
\hline & & \\
\hline & LUUDSKÝ PREKLAD & GOOGLE PREKLAD \\
\hline $\begin{array}{l}\text { FREKVENTOVANÉ } \\
\text { TERMIINY }\end{array}$ & PREKLAD DO SJ & PREKLAD DO SJ \\
\hline $\begin{array}{l}\text { 1. STATE } \\
\text { State aid: } \\
\text { State budget: }\end{array}$ & $\begin{array}{l}\text { - štátna pomoc: } 8 \\
\text { - štátny rozpočet: } 4\end{array}$ & $\begin{array}{l}\text { - štátna pomoc: } 8 \\
\text { - štátny rozpočet: } 4\end{array}$ \\
\hline $\begin{array}{l}\text { 2. MEMBER } \\
\text { Member states: } \\
\text { Full member: }\end{array}$ & $\begin{array}{l}\text { - členské štáty: } 1837 \\
\text { - riadny člen: } 1\end{array}$ & $\begin{array}{l}\text { - členské štáty: } 2093 \\
\text { - riadny člen: } 1\end{array}$ \\
\hline $\begin{array}{l}\text { 3. EUROPEAN } \\
\text { European Agency: } \\
\text { European Parliament: } \\
\text { European Union: } \\
\text { European integration: }\end{array}$ & $\begin{array}{l}\text { - Európska agentúra: } 1 \\
\text { - Európsky parlament: } 374 \\
\text { - Európska únia: } 329 \\
\text { - európska integrácia: } 8\end{array}$ & $\begin{array}{l}\text { - Európska agentúra: } 1 \\
\text { - Európsky parlament: } 513 \\
\text { - Európska únia: } 478 \\
\text { - európska integrácia: } 13\end{array}$ \\
\hline $\begin{array}{l}\text { 4. COMMISSION } \\
\text { Commission proposal: } \\
\text { European Commission: }\end{array}$ & $\begin{array}{l}\text { - návrh komisie: } 12 \\
\text { - Európska komisia: } 5\end{array}$ & $\begin{array}{l}\text { - návrh komisie: } 12 \\
\text { - Európska komisia: } 79\end{array}$ \\
\hline $\begin{array}{l}\text { 5. ARTICLE } \\
\text { Following article: } \\
\text { Defined in article: }\end{array}$ & $\begin{array}{l}\text { - nasledujúce články: } 3 \\
\text { - definované v článku: } 19 \\
\text { - vymedzené v článku: } 13\end{array}$ & $\begin{array}{l}\text { - nasledujúce články: } 6 \\
\text { - definované v článku: } 77 \\
\text { - vymedzené v článku: } 0\end{array}$ \\
\hline
\end{tabular}




\begin{tabular}{|c|c|c|}
\hline $\begin{array}{l}\text { 6. COUNCIL } \\
\text { Council of Ministers: } \\
\text { Council meeting: } \\
\text { Council decision: }\end{array}$ & $\begin{array}{l}\text { - Rada ministrov: } 5 \\
\text { - zasadanie Rady: } 4 \\
\text { - zasadnutie Rady: } 1 \\
\text { - rozhodnutie Rady: } 73\end{array}$ & $\begin{array}{l}\text { - Rada ministrov: } 9 \\
\text { - zasadnutie Rady: } 11 \\
\text { - rozhodnutie Rady: } 101\end{array}$ \\
\hline $\begin{array}{l}\text { 7. DIRECTIVE } \\
\text { Framework directive: } \\
\text { Council directive: } \\
\text { Proposal for a directive: }\end{array}$ & $\begin{array}{l}\text { - rámcová smernica: } 2 \\
\text { - smernica Rady: } 343 \\
\text { - návrh smernice: } 7\end{array}$ & $\begin{array}{l}\text { - rámcová smernica: } 2 \\
\text { - smernica Rady: } 363 \\
\text { - návrh smernice: } 5\end{array}$ \\
\hline $\begin{array}{l}\text { 8. MARKET } \\
\text { Market value: } \\
\text { Capital market: } \\
\text { Financial market: } \\
\text { Market conditions: }\end{array}$ & $\begin{array}{l}\text { - trhová hodnota: } 19 \\
\text { - kapitálový trh: } 13 \\
\text { - finančný trh: } 99 \\
\text { - trhové podmienky: } 9 \\
\text { - podmienky na trhu: } 8\end{array}$ & $\begin{array}{l}\text { - trhová hodnota: } 29 \\
\text { - kapitálový trh: } 22 \\
\text { - finančný trh: } 112 \\
\text { - trhové podmienky: } 2 \\
\text { - podmienky na trhu: } 9\end{array}$ \\
\hline $\begin{array}{l}\text { 9. PARLIAMENT } \\
\text { National Parliament }\end{array}$ & - Národný parlament: 5 & - Národný parlament: 12 \\
\hline $\begin{array}{l}\text { 10. NATIONAL } \\
\text { National Central bank }\end{array}$ & $\begin{array}{l}\text { - Národná centrálna banka: } \\
231\end{array}$ & $\begin{array}{l}\text { - Národná centrálna banka: } \\
282\end{array}$ \\
\hline $\begin{array}{l}\text { 11. POLICY } \\
\text { Policy instrument }\end{array}$ & - nástroj politiky: 24 & - nástroj politiky: 3 \\
\hline $\begin{array}{l}\text { 12. MEASURES } \\
\text { Adopt measures: } \\
\text { Support measures: } \\
\text { Preventive measures: }\end{array}$ & $\begin{array}{l}\text { - prijat' opatrenia: } 13 \\
\text { - opatrenia na podporu: } 4 \\
\text { - preventívne opatrenia: } 4\end{array}$ & $\begin{array}{l}\text { - prijat' opatrenia: } 20 \\
\text { - opatrenia na podporu: } 5 \\
\text { - preventívne opatrenia: } 4\end{array}$ \\
\hline $\begin{array}{l}\text { 13. AMENDMENT } \\
\text { Proposed amendment: } \\
\text { Technical amendment: }\end{array}$ & $\begin{array}{l}\text { - navrhované zmeny: } 3 \\
\text { - technická zmena: } 3\end{array}$ & $\begin{array}{l}\text { - navrhované zmeny: } 4 \\
\text { - technická zmena: } 3\end{array}$ \\
\hline $\begin{array}{l}\text { 14. UNION } \\
\text { Trade Union: } \\
\text { Monetary Union: }\end{array}$ & $\begin{array}{l}\text { - odbory: } 2 \\
\text { - odborové organizácie: } 2 \\
\text { - menová únia: } 47\end{array}$ & $\begin{array}{l}\text { - odbory: } 0 \\
\text { - odborové organizácie } 4 \\
\text { - menová únia: } 66 \text { : }\end{array}$ \\
\hline $\begin{array}{l}\text { 15. COMMITTEE } \\
\text { Advisory Committee: } \\
\text { Joint Committee: }\end{array}$ & $\begin{array}{l}\text { - poradný výbor: } 5 \\
\text { - orgán určený pre: } 0 \\
\text { - spoločný výbor: } 3\end{array}$ & $\begin{array}{l}\text { - poradný výbor: } 4 \\
\text { - orgán určený pre: } 1 \\
\text { - spoločný výbor: } 4\end{array}$ \\
\hline $\begin{array}{l}\text { 16. AUTHORITIES } \\
\text { Administrative authorities: } \\
\text { Competent authorities: }\end{array}$ & $\begin{array}{l}\text { - správne orgány: } 6 \\
\text { - administratívne orgány: } 3 \\
\text { - príslušné orgány: } 142\end{array}$ & $\begin{array}{l}\text { - správne orgány: } 9 \\
\text { - administratívne orgány: } 0 \\
\text { - príslušné orgány: } 251\end{array}$ \\
\hline
\end{tabular}




\begin{tabular}{|c|c|c|}
\hline $\begin{array}{l}\text { 17. IMPLEMENTATION } \\
\text { Date of implementation: } \\
\text { Implementation of regulation: }\end{array}$ & $\begin{array}{l}\text { - od dátumu: } 1 \\
\text { - odo dňa: } 1 \\
\text { - do dátumu: } 1 \\
\text { - realizácia nariadenia: } 1 \\
\text { - vykonávat' nariadenie: } 1 \\
\text { - uplatňovat' nariadenie: } 1\end{array}$ & $\begin{array}{l}\text { - odo dňa: } 3 \\
\\
\text { - vykonávat' nariadenie: } 1 \\
\text { - uplatňovat' nariadenie: } 3\end{array}$ \\
\hline $\begin{array}{l}\text { 18. TREATY } \\
\text { Acession Treaty: } \\
\text { Constitutional Treaty: }\end{array}$ & $\begin{array}{l}\text { - zmluva o pristúpení: } 1 \\
\text { - akt o pristúpení: } 1 \\
\text { - Ústavná zmluva: } 10\end{array}$ & $\begin{array}{l}\text { - zmluva o pristúpení: } 3 \\
\text { - Ústavná zmluva: } 10\end{array}$ \\
\hline $\begin{array}{l}\text { 19. LEGISLATION } \\
\text { Community legislation: } \\
\text { Relevant legislation: }\end{array}$ & $\begin{array}{l}\text {-právne predpisy } \\
\text { spoločenstva: } 36 \\
\text { - relevantná právna úprava: } 1 \\
\text { - relevantná právna úprava: } 5\end{array}$ & $\begin{array}{l}\text { - právne } \\
\text { predpisy } \\
\text { spoločenstva: } \\
44 \\
\text { - príslušné } \\
\text { právne } \\
\text { predpisy: } 6\end{array}$ \\
\hline $\begin{array}{l}\text { 20. INSTITUTION } \\
\text { Lending institution: } \\
\text { Credit institution: }\end{array}$ & $\begin{array}{l}\text { - úverová inštitúcia: } 1 \\
\text { - úverová inštitúcia: } 327 \\
\text { - peňažná finančná inštitúcia: } \\
7 \\
\text { - úverové ústavy: } 7 \\
\text { - peňažné finančné ústavy: } 5\end{array}$ & $\begin{array}{l}\text { - úverová } \\
\text { inštitúcia: } 1 \\
\text { - úverová } \\
\text { inštitúcia: } \\
432\end{array}$ \\
\hline
\end{tabular}

Z výskumu slovných spojení v textoch EÚ vyplýva, že Google verzia ich prekladu je opät' porovnatel'ná s verziou l'udského prekladu. V l'udskom preklade môžeme sledovat' istú variabilitu terminologických spojení, pričom Google použiva väčšinou len jeden $\mathrm{z}$ variantov. Napr. spojenie defined in article sa v l'udskom preklade objavilo ako definované v článku a aj ako vymedzené včlánku, pričom Google preložil toto spojenie len ako definované včlánku. Podobnú situáciu predstavuje spojenie council meeting, v prípade ktorého l'udský preklad zahŕňa oba dvojtvary zasadanie rady i zasadnutie rady a preklad Google použil len tvar zasadnutie. V prípade spojenia administrative authorities Google jednoznačne toto spojenie prekladal ako správne orgány, pričom človek pripustil okrem tohto spojenia aj doslovný preklad administrativne orgány. Pomerne prekvapivý výsledok sme zaznamenali pri preklade spojenia market conditions. V tomto prípade preklad Google rovnako ako l'udský preklad prevzal obe možnosti - predložkový tvar podmienky na trhu a tiež adjektívny tvar trhové podmienky. Ako sa ukázalo, laický i skúsený prekladatel' sa i v prípade terminologických slovných spojení často môže spol'ahnút' na preklad Google.

\section{Záver}

Z výsledkov výskumu je možné potvrdit', že kvalita strojového prekladu je pomerne výrazne závislá od kvality vstupného materiálu a v princípe kopíruje prob- 
lémy, s ktorými sa pri práci stretáva l'udský prekladatel'. Divergencia v oblasti terminológie nie je výrazne odlišná od prekladu realizovaného l'udským prekladatel’om tento jav je čiastočne možné vysvetlit' skutočnost'ou, že pri tvorbe štatistických prekladových systémov sa primárne používa obrovská databáza bilingválnych textov (prekladov), ktoré boli vytvorené l'udským prekladatel'om, pričom následne dochádza $\mathrm{k}$ jej štatistickej analýze, počítačovému spracovaniu a sprístupneniu vo forme strojového prekladu. Inými slovami, úspech strojového prekladu závisí od vstupného textu, ktorý realizuje l'udský prekladatel' a medzi týmito dvomi typmi prekladu vzniká paralelizmus ( $\mathrm{v}$ našom prípade $\mathrm{v}$ oblasti divergencie prekladu terminologických jednotiek). Kvalitu štatistického strojového prekladu je možné okrem zdokonal'ovania štatistických a pravidlových algoritmov zlepšit' dvoma základnými postupmi: (1) zvyšovaním kvality vstupných textov a (2) zvyšovaním ich počtu. Čím viac kvalitných bilingválnych textov preložených l'udským prekladatel'om bude mat' strojový prekladač k dispozícii, tým kvalitnejší bude jeho výsledný preklad.

\section{Bibliograpic references}

BAKER, M. - SALDANHA, G. 2008. Routledge Encyclopedia of Translation studies. Routledge. ISBN 04156093844.

BELL, R. T. 1991. Translation and Translating: Theory and practice. Routledge. ISBN 0-582-01648-7.

BIROVA, J. - BARANCOVA, M. - SIMKOVA, Z. 2016. A note on terminology: Bilingualism, plurilingualism and plurilingual intercultural competence or are we all plurilingual? [K pojmosloviu bilinvizmu, plurilingvizmu a viacjazycnej interkulturnej kompetencii alebo sme vsetci viacjazycni?]. In: XLinguae, vol 9, n. 2, pp. 114-127. ISSN 1337-8384.

BORISOVA, O. V. - VASBIEVA, D. G. - MALYKH, N. I. - VASNEV, S. A. BIROVA, J. 2016. Enhancement of Students Vocabulary Learning Through a Blended Approach. In: Mathematics Education, vol. 11, n. 5, pp. 1195-1203. ISSN 13063030

BYRNE, J. 2010. Technical Translation. Usability Strategies for Translating Technical Documentation. Springer. ISBN 9048171620.

DEKANOVA, E. 2009. Kapitoly z teorie a didaktiky prekladu odbornych textov. Nitra: Filozoficka fakulta UKF. ISBN 978-80-8094-598-5.

GROMOVA, E. et al. (ed.) Odborny preklad 1. 2005. Ucelova publikacia Slovenskej spolocnosti prekladatelov odbornej literatury. Bratislava: AnaPress. ISBN 80-8913708-3.

GROMOVA, E. - MUGLOVA, D. 2013. Pragmaticke aspekty civilizacno-kulturnych procesov v translacii v narodnom i nadnarodnom kontexte. In: XLinguae Journal, vol. 6, n. 2, pp. 64-90. ISSN 1337-8384 .

HAJIKOVA, A. 2005. Slovenska a anglicka terminologia EU (Prekladatelske postupy). In: Odborny preklad 1. Ucelova publikacia Slovenskej spolocnosti prekladatelov odbornej literatury. ISBN 80-89137-08-3.

HAIS, K. - HODEK, B. 1993. Velky anglicko-cesky slovnik. Praha: Academia. ISBN 80-200-0064-X.

HORECKY, J. 2007. O prekladani terminologie. In: Antologie teorie odborneho prekladu (vyber z praci ceskych a slovenskych autoru). Ostrava: Ostravska univerzita v Ostrave, Filozoficka fakulta. pp. 58-62. ISBN 978-80-7368-383-2.

HOUSE, J. 1997. Translation Quality Assessment: A model Revisited. Gunter Naar Verlag. ISBN 3-8233-5075-7. 
JANECOVA, E. 2012. Interkulturny dialog $\mathrm{v}$ tradicnom a novodobom mysleni o preklade. In: Tradicia a inovacia $\mathrm{v}$ translatologickom vyskume III. Nitra: UKF, pp. 18-32. ISBN 978-80-558-0123-0.

MAN, O. 2007. Otazky ekvivalence v odbornem prekladu. In: Antologie teorie odborneho prekladu (vyber z praci ceskych a slovenskych autoru). Ostrava: Ostravska univerzita v Ostrave, Filozoficka fakulta. pp. 130-136. ISBN 978-80-7368-383-2.

MASAR, I. 1991. Prirucka slovenskej terminologie. Bratislava: Veda. ISBN 8022403415.

MISTRIK, J. 1993. Encyklopedia jazykovedy. Bratislava: Obzor. ISBN 8021502509

MUNDAY, J. 2001. Introducing Translation Studies: Theory and applications. New York: Routledge. ISBN 0-415-22927-2.

MUNKOVA, D. 2013. Pristupy k strojovemu prekladu: modely, metody a problemy strojoveho prekladu. Nitra: UKF. ISBN 978-80-558-0450-7.

MUGLOVA, D. 2009. Komunikacia, tlmocenie, preklad alebo preco spadla Babylonska veza?. Bratislava: Enigma Puglishing. ISBN 978-80-89132-82-9.

PANISOVA, L. 2013. Preklad substandardnej lexiky. In: Muglova et al. (ed.) Zrkadla translatologie I. Preklad ako nastroj komunikacie. Presov: Presovská univerzita, pp. 167-176. ISBN 978-80-555-0784-2.

PAVEL, S. - NOLET, D. 2002. Handbook of terminology. Canada: Translation Bureau. ISBN 9780660187983.

ROGERS, M. 2007. Terminological equivalence: Probability and consistency in technical translation. In: EU-High-Level Scientific Conference Series. In: MuTra 2007 - LSP

Translation Scenarios: Conference Proceedings. Vienna. 2007 [online] Dostupne na internete:

http://www.euroconferences.info/proceedings/2007_Proceedings/2007_Rogers_Margr et.pdf

SMOLIK, M.: Lokalizacia softveru ako timova praca. In: Odborny preklad 4. Bratislava: Ana Press. ISBN 80-89137-57-2. [online] Dostupne na internete: http://www.sspol.sk/files/op4.pdf

STECOVA, A. 2009. Preklad technickej dokumentacie (v rusko-slovenskom plane). In: 4. studentska vedecka konferencia, Presov: Presovska univerzita. ISBN 978-808068-969-8. [online] Dostupne na internete:

http://www.pulib.sk/web/kniznica/elpub/dokument/Sipko2/subor/28_7.pdf

Words: 4345

Characters: 31244

Lýdia Čechová, PhD.

Department of Translation Studies

Constantive the Philosopher University

Štefánikova 67, Nitra 94974

Slovak Republic

lydiacech@gmail.com

Martin Mačura, $\mathrm{PhD}$.

Columbus Slovakia

Wilsonovo nábrežie 112, Nitra 94901

Slovaka Republic

martin.macura@columbus.sk 
Mgr. Lenka Kubušová

Fond na podporu umenia

Cukrová 14, Bratislava 81108

Slovak Republic

kubusova222@gmail.com

Mgr. Zuzana Jánošíková

Department of Translation Studies

Constantive the Philosopher University

Štefánikova 67, Nitra 94974

Slovak Republic

zujanosik@gmail.com 